\title{
The Adrenocortical Function of Brain Tumor Patients
}

\section{Tohru UOZUMI}

\author{
The First Department of Surgery, Osaka University Medical School \\ (Director : Prof. Yoshiaki Takeda, M.D.)
}

In order to obtain the indicator endocrinologically for the improvement of pre-, per, and postoperative procedures against brain tumor in patients, 69 cases of these cases were examined concerning their pituitary-adrenocortical functions. In these series, ACTH-Z test was employed to measure the adrenocortical responses quantitatively through urinary 17-OHCS. For the estimation of preoperative status, "Adrenocortical response to Corticotropin," (Acr-G), and for the postoperative career, "Adrenocortical response to Operation," (Acr-O), and “Adrenocortical response-Index", (Acr-I) were devised through the measurement of urinary 17-OHCS respectively.

1) In normal subjects, Acr-G range was $8.0-42.0 \mathrm{mg}$. In 69 brain tumor patients, 3 groups were classfied ; 14 cases showed hypo-reactive, 11 cases showed hyper-reactive and others were normo-reactive responses. The hyper-reactive responses are considered to be a specific phenomenon observed among the brain tumor cases.

2) The evidence by the measurement of Acr-O, and Acr-I showed a remarkable decrease of the adrenocortical response it those brain tumor cases who had undergone operations under artificial hibernation as compared with those patients under normothermic anesthesia.

\section{Experimental Studies on the Steroid Aromatization}

\author{
Minoru AMATSU \\ Department of Obstetrics and Gynecology, Kyoto Prefectural University of Medicine
}

(Director : Prof. Gen-ichi Tokuda)

Estrogen has been well known for many years, but the entire route of its biosynthesis has not yet been sufficiently understood. It has been recently reported by Ryan that a conversion experiment was made to obtain Estrogens from some steroids in vitro by using placental aromatizing enzyme system.

The principal target was the possibility of conversion of 19-Norsteroids to Estrogen. These 19-Norsteroids are of great interest as a potent progestin.

Quantitative measurement of Estrogens was performed by a modified Engel's method. The extraction from the tissue was done by acetone. Additional washing with toluene proved more effective in cleaning out the substrate as well as in removing the impurities.

Stimmel's almina column chromatography method was perfomed for the purified fractionation of Estrogen

Hydroquinone Kober reaction also was used for colorimetric determinaton, according to Brown's mdthod.

It was learned empirically during the course of such experiments that the quality of sulfuric acid could bring about a diversity in results.

Vol. 38 No. 12 


\title{
脳腫瘍患者の副腎皮質機能に関する臨床的研究
}

\author{
(昭和37年11月 2 日受付) \\ 目次

\begin{tabular}{ll|llr} 
I & 緒 & I & 考 & 按 \\
II & 研究対象及び研究方法 & V & 結 & 諭 \\
III & 成 績 & & 参考交献
\end{tabular}

大阪大学医学部符一外科学教室（指導 武田義章教授）

魚住徹

\section{I 緒 言}

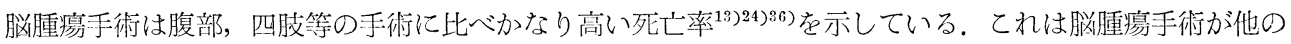
諸手術に比し生体に大きな影響を及ぼ，しかも術後管理のむづかしいものであるてとを示している.

脳腫崵手術時に考慮すべき因子としては出血性ショック；Herniation；脳幹の承吸循環中枢の障害；自律 神経に対する直接侵襲；術前より存在する内分泌系や自律神経系の機能不全；及び合併症（主に心，肺，朋， 腎等) 等がある，ての中，内分泌系並びに自律神経系の失調については，脳下垂体及び視床下部の腫腸に対 する手術の場合に解剖所見に於て視床下部の猿死出血等の所見 ${ }^{3435}$ の確認されたものもあるが，それ以外の 部位の腫愓の場合には形態的，機能的変化の確認は殆どなされていない，ての様な内分泌系の失調に対する

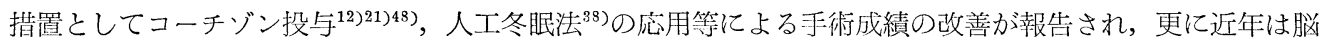
手術時の出血，脳浮腫等に対して低体温法 ${ }^{42}$ が導入され，てれが生体の受ける影響をも小ならしめ得るとす る報告もある。

しかし，上述の様な庇護的措置の裏付けとなる内分泌系の機能と反応の関係は適確に諭じられていない。

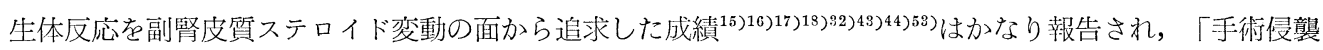
の大小」というが如き促来漠然と用いられて来た表現と副腎皮質ステロイドの变動との間の関係を検討して いるが，未だての問題は適確に量的に論じられていない。

脸腫瘍手術時の副腎皮質反応に関する成績は極めて少数例を取扱つた報告9)を見るに過ぎない，手術侵襲 と副腎皮質反応との関係を論ずる為にはまず第 1 亿対象とした患者の術前の副婜皮質機能が検討されなけれ ばならない，何となれば異なる副腎皮質機能を有する各個体の手術に対する副腎皮質反応は異なるという事 実(62945)があるからである。第 2 亿，手術方法を検討せねばならない，何となれば異なる手術によつて，異

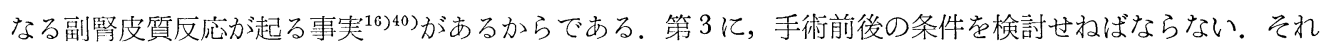

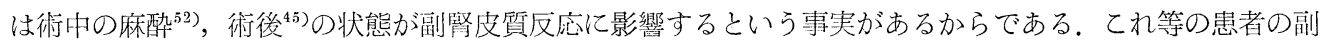
箐皮質機能，手術に対する副腎皮質反応を相互に比較する為には，乙れを一定の方式に従つて量的に表現す る必要がある，以上の観点から，著者は脳腫晹手術の患者管理を改善する指標を得る為に，副婜皮質反応の 立場から脳腫瘍患者の病態生理を追求した，即ち第 1 亿脳腫瘍患者の術前の副腎皮質反応性の追求，第 2 亿 各症例の手術に対する副腎皮質反応の追求，第 3 亿手術に際して用いた麻酔，即ち常温下插管麻酔と人工冬 眠法の副腎皮質反応に及ぼす影響の検討の 3 段階に分ち，各段階について数量的表現を行なつて，脳腫瘍手 術の脳下垂体副緊皮質系に及ぼす侵襲の程度を検討した結果, 認むべき成績を得たのでここに報告する。 
Table 1. Brain Tumor Patients included in this Study

\begin{tabular}{l|r|r}
\hline \multicolumn{1}{c|}{ Case of Tumors } & No. & Operated \\
\hline A. Pituitary Tumor & 16 & 11 \\
B. Craniopharyngioma & 7 & 5 \\
C. Postsellar Tumor & 2 & 1 \\
D. Tumor in Middle Cranial Fossa & 3 & 3 \\
E. Frontal Tumor & 6 & 5 \\
F. Parieto-occipital Tumor & 6 & 6 \\
G. Pinealoma & 2 & 1 \\
H. Tumor in III-Ventricle & 1 & 0 \\
I. Tumor in Brain-Stem & 11 & 3 \\
J. Cerebellar Tumor & 12 & 12 \\
K. Cerebellopontine-Angle Tumor & 69 & 57 \\
\hline \multicolumn{2}{c}{ Total } & \\
\hline
\end{tabular}

\section{II 研究対象及び研究方法}

\section{A. 研究対象}

研究対象は1957年 9 月より1961年

6 月迄に大阪大学医学部第 1 外科教 室で経験された脳腫瘍の症例の中， 69例である. (Table 1) 何れも臨床 上心，肺，朋婜の機能障害その他の 合併症を認めない症例である。

副筱皮質機能テストに関する対照 例は健康成人男女25例である. 又手 術に関する対照例は一側肺上葉切除 を施行した軽症肺結核患者10例で, 何れも内分泌系, 自律神経系に機能 異常を㦘めず又合併症を伴わない症 例である.

\section{B. 副腎皮質機能検查法}

1. 尿中総 17-Hydroxycorticosteroidsteroid (17-OHCS) 排泄量の測定法尿中総 17-OHCS 排泄量の測定は Porter-Silber ${ }^{39}$, Reddy-Smith ${ }^{41}$ 法, 熊谷 ${ }^{54}$ 変法によつた.

\section{2. 尿中総 17-OHCS 基礎排泄量}

無負荷安静時，24時間尿中の総 17-OHCS 排泄量をもつて基礎排泄量とした。 2 回乃至 5 〜 回の測定の 平均值を求めた。

3. ACTH-Z テスト

渡边 ${ }^{54}$ 等の発表した ACTH-Z テストに準拠した。

Fig. 1. Adrenocortico-response to Corticotropin (Acr-G)

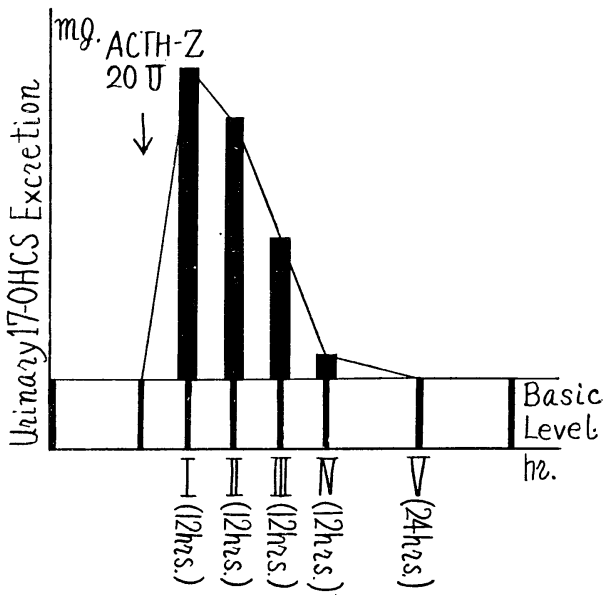

Adrenocorticoresponse to Corticotropin mg. (Acr-G) $=(\mathrm{I}+\mathrm{II}+\mathrm{III}+\mathrm{IV}+\mathrm{V})-3 \cdot$ Basic Level
Fig. 2. Adrenocortico-response to Operatson (Acr-O)

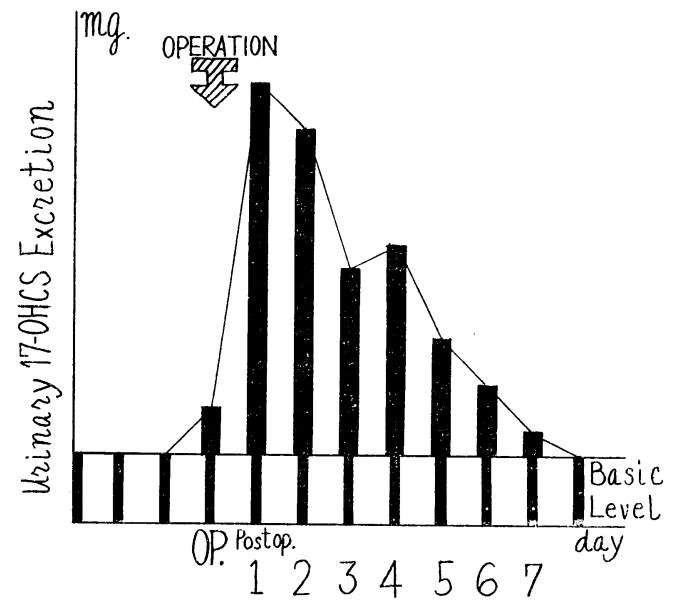

Adrenocortico-response to Operation mg. (Acr-O) $=($ OP. + Postop. $-1+2+\cdots+7)-8 \cdot$ Basic Level 
4. 負荷反応量の設定 Adrenocortico-response to Corticotropin, Acr-C)

ACTH-Z テストに於ける副腎皮質反応性を数量的に表現する為に次のような数式に従つて ACTH-Z に 対する尿中総 17-OHCS の反応増加分の和を算出した.

「負荷反応量 $」 \mathrm{mg}=(\mathrm{I}+\mathrm{II}+\mathrm{III}+\mathrm{IV}+\mathrm{V})$ - 基礎排泄量 $\times 3$ (Fig. 1)

\section{5. 手術前後の尿中総 17-OHCS 排泄量の測定}

術当日，術後1日目，2日目〜 7 日目迄連日総 17-OHCS 排泄量を測定した.

\section{6. 手術反応量の設定}

(Adrenocortico-response to Operation, Acr-O)

手術に対する副腎皮質の反応を数量的に表現して比較検討を便ならしめる為に次の様な数式により，術当 日より術後7日目迄に到る間の尿中総 17-OHCS 排泄量の基礎排泄量よりの増加分の総和をとつて，乙れを 「手術反応量」と名付けた。即ち

「手術反応量」 $\mathrm{mg}=$ （術当日＋術後 1 日目 $+\cdots \cdots+$ 術後 7 日目）－基礎排泄量 $\times 8$ (Fig. 2)

$$
\text { III 成績 }
$$

\section{A. 尿中総 17-OHCS 基礎排泄量}

\section{1. 対照例}

基礎排泄量は（Table 2）2.8～12.3mg/日の範囲に分布し，平均值は $7.9 \pm 2.5 \mathrm{mg} /$ 日である。軽症肺結核 症例10例の基礎排泄量は (Table 3)，4.8〜 12.3mg/日の範囲に分布し，平均值は7.7士2.5mg/日である. この 2 つの值の間に有意の差はない.

Table 2. ACTH-Z-test in 25 Normal Cases (Urinary total 17-OHCS, mg)

\begin{tabular}{|c|c|c|c|c|c|c|c|c|c|}
\hline Case & Age & Sex & $\begin{array}{l}\text { Basic } \\
\text { Level }\end{array}$ & I & II & III & IV & $\mathrm{V}$ & Acr-C \\
\hline 1 & 21 & $\hat{\jmath}$ & 9.1 & 17.2 & 9.9 & 20.0 & 1.7 & 12.9 & 34.4 \\
\hline 2 & 22 & 우 & 7.3 & 18.3 & 18.6 & 6.2 & 9.1 & 10.9 & 41.2 \\
\hline 3 & 38 & $\hat{\jmath}$ & 8.0 & 25.0 & 13.0 & 11.2 & 5.8 & 8.0 & 39.0 \\
\hline 4 & 26 & $\hat{\beta}$ & 8.0 & 10.4 & 16.8 & 8.2 & 6.0 & 2.7 & 20.1 \\
\hline 5 & 34 & 우 & 7.7 & 20.5 & 10.2 & 8.4 & 4.7 & 16.1 & 36.8 \\
\hline 6 & 52 & 우 & 8.8 & 7.1 & 14.8 & 4.9 & 3.2 & 13.2 & 16.8 \\
\hline 7 & 24 & $\hat{\jmath}$ & 10.2 & 4.6 & 15.5 & 8.4 & 9.2 & 11.4 & 18.5 \\
\hline 8 & 22 & 令 & 12.3 & 13.1 & 16.5 & 13.2 & 5.6 & 4.2 & 15.7 \\
\hline 9 & 16 & $\hat{\jmath}$ & 4.2 & 9.0 & 3.9 & 3.8 & 3.0 & 7.2 & 14.3 \\
\hline 10 & 18 & 令 & 6.1 & 11.2 & 4.8 & 7.5 & 2.8 & 9.3 & 17.3 \\
\hline 11 & 22 & 우 & 4.3 & 2.3 & 12.5 & 6.6 & 5.9 & 10.0 & 24.4 \\
\hline 12 & 15 & 令 & 8.8 & 12.1 & 5.2 & 3.2 & 5.7 & 11.2 & 11.0 \\
\hline 13 & 28 & $\hat{\delta}$ & 5.7 & 6.8 & 12.8 & 5.9 & 1.8 & 6.3 & 16.5 \\
\hline 14 & 38 & 우 & 10.0 & 16.7 & 13.4 & 7.3 & 2.2 & 9.7 & 19.3 \\
\hline 15 & 37 & 오 & 10.3 & 17.2 & 16.5 & 8.4 & 4.0 & 17.3 & 32.5 \\
\hline 16 & 26 & 우 & 7.0 & 19.5 & 13.7 & 8.2 & 2.3 & 4.5 & 27.5 \\
\hline 17 & 29 & 우 & 10.0 & 13.5 & 18.0 & 11.5 & 8.4 & 8.2 & 39.6 \\
\hline 18 & 30 & $\hat{o}$ & 2.8 & 11.4 & 9.1 & 2.0 & 1.9 & 6.1 & 22.1 \\
\hline 19 & 18 & 우 & 4.6 & 12.8 & 12.6 & 3.0 & 2.4 & 2.2 & 19.2 \\
\hline 20 & 49 & 우 & 6.0 & 10.0 & 14.0 & 6.5 & 3.3 & 5.2 & 21.0 \\
\hline 21 & 23 & $\hat{o}$ & 10.2 & 18.4 & 17.9 & 7.5 & 3.7 & 7.4 & 24.3 \\
\hline
\end{tabular}




\begin{tabular}{|c|c|c|c|c|c|c|c|c|c|}
\hline 22 & 36 & $\hat{o}$ & 11.2 & 17.0 & 14.8 & 9.1 & 6.4 & 10.0 & 23.7 \\
\hline 23 & 31 & 우 & 8.8 & 17.1 & 14.8 & 4.9 & 3.2 & 13.0 & 26.6 \\
\hline 24 & 28 & $\hat{o}$ & 4.8 & 14.0 & 11.4 & 4.3 & 5.6 & 6.9 & 27.8 \\
\hline 25 & 30 & $\hat{\delta}$ & 10.4 & 17.2 & 14.9 & 10.0 & 6.7 & 12.9 & 30.5 \\
\hline \multicolumn{3}{|c|}{ Mean } & $\begin{array}{r}7.9 \\
\pm 2 .\end{array}$ & $\begin{array}{l}13.7 \\
\pm 5 .\end{array}$ & $\begin{array}{r}13.0 \\
\pm 4\end{array}$ & $\begin{array}{r}7.6 \\
\pm 3 .\end{array}$ & 6 & $\begin{array}{l}9.1 \\
\pm 3\end{array}$ & $\begin{array}{r}24.8 \\
\quad \pm 8.6 \\
\end{array}$ \\
\hline
\end{tabular}

Table 3. ACTH-Z-test in 10 Pulmonary tbc. Patients (Urinary total 17-OHCS, mg)

\begin{tabular}{|c|c|c|c|c|c|c|c|c|c|}
\hline Case & Age & Sex & $\begin{array}{l}\text { Basic } \\
\text { Level }\end{array}$ & I & II & III & IV & $\mathrm{V}$ & Acr-C \\
\hline 1 & 22 & $\hat{o}$ & 11.1 & 11.7 & 10.0 & 25.3 & 3.7 & 7.4 & 24.8 \\
\hline 2 & 24 & 우 & 4.9 & 12.9 & 8.1 & 5.0 & 1.0 & 5.0 & 17.3 \\
\hline 3 & 28 & $\hat{o}$ & 6.1 & 24.8 & 17.1 & 5.4 & 4.8 & 1.8 & 35.6 \\
\hline 4 & 31 & $\hat{o}$ & 7.2 & 24.2 & 11.8 & 8.4 & 7.0 & 4.8 & 34.6 \\
\hline 5 & 29 & 우 & 8.4 & 19.0 & 16.2 & 13.0 & 8.2 & 9.2 & 40.4 \\
\hline 6 & 26 & $\hat{\jmath}$ & 4.8 & 13.0 & 8.3 & 6.0 & 3.0 & 4.2 & 20.1 \\
\hline 7 & 30 & $\hat{o}$ & 7.2 & 14.3 & 9.2 & 8.2 & 4.3 & 4.8 & 19.2 \\
\hline 8 & 26 & $\hat{o}$ & 12.3 & 13.5 & 17.8 & 10.2 & 8.2 & 11.0 & 23.8 \\
\hline 9 & 27 & 우 & 9.2 & 17.4 & 13.2 & 5.8 & 8.0 & 8.2 & 25.0 \\
\hline 10 & 28 & 우 & 6.1 & 12.1 & 5.0 & 6.0 & 3.2 & 4.3 & 12.3 \\
\hline \multicolumn{3}{|c|}{ Mean } & $\begin{array}{l}7.7 \\
\pm 2.5\end{array}$ & $\begin{array}{r}16.3 \\
\pm 4\end{array}$ & $\begin{array}{r}11.7 \\
\pm 4\end{array}$ & ${ }^{9.3} \pm 6$ & 1.2. & $\begin{array}{l}1 \\
\pm 2 \\
\end{array}$ & $\begin{array}{r}5.3 \\
\quad+9.0 \\
\end{array}$ \\
\hline
\end{tabular}

\section{2. 脳腫瑒例}

脳下垂体腫瘍症例16例の平均値は $9.9 \mathrm{mg} /$ 日で, 対照より高値を示すが分散は極めて大きい. クラニオフ

Table 4. ACTH-Z-test in 69 Brain Tumor Patients (Urinary total 17-OHCS, mg)

\begin{tabular}{|c|c|c|c|c|c|c|c|c|}
\hline \multicolumn{2}{|c|}{ Case } & $\begin{array}{l}\text { Basic } \\
\text { Level }\end{array}$ & I & II & III & IV & $\mathrm{V}$ & Acr-C \\
\hline \multirow{17}{*}{ A } & 1 & 28.3 & 24.4 & 27.5 & 28.8 & 25.0 & 18.7 & 39.5 \\
\hline & 2 & 8.2 & 6.1 & 4.7 & 3.3 & 1.0 & 7.0 & -2.5 \\
\hline & 3 & 5.0 & 4.4 & 11.5 & 2.7 & 1.3 & 0.7 & 5.6 \\
\hline & 4 & 0 & 1.0 & 1.2 & 2.3 & 0.6 & 1.9 & 7.0 \\
\hline & 5 & 13.3 & 13.7 & 26.2 & 13.4 & 5.4 & 15.6 & 34.4 \\
\hline & 6 & 7.6 & 6.0 & 9.5 & 2.6 & 3.6 & 7.0 & 5.9 \\
\hline & 7 & 1.5 & 0.3 & 3.8 & 1.9 & 0.2 & 1.7 & 3.4 \\
\hline & 8 & 7.8 & 4.8 & 4.9 & 4.9 & 2.5 & 9.1 & 2.8 \\
\hline & 9 & 14.9 & 18.3 & 13.3 & 19.4 & 5.9 & 15.2 & 27.4 \\
\hline & 10 & 8.8 & 10.3 & 19.0 & 9.8 & 3.5 & 8.5 & 24.7 \\
\hline & 11 & 8.4 & 13.4 & 14.6 & 5.6 & 4.6 & 6.5 & 19.5 \\
\hline & 12 & 9.4 & 9.1 & 6.2 & 3.2 & 1.3 & 1.4 & -7.0 \\
\hline & 13 & 13.8 & 17.7 & 14.3 & 11.8 & 3.2 & 13.9 & 19.5 \\
\hline & 14 & 11.2 & 14.1 & 20.1 & 11.2 & 5.5 & 10.7 & 28.0 \\
\hline & 15 & 9.0 & 19.3 & 23.1 & 9.4 & 26.8 & 16.7 & 68.4 \\
\hline & 16 & 11.2 & 6.7 & 15.8 & 9.2 & 9.3 & 6.7 & 14.1 \\
\hline & Mean & $9.9 \pm 6.3$ & 10.6 & 13.5 & 8.7 & 6.2 & 8.8 & $18.2 \pm 19.0$ \\
\hline
\end{tabular}




\begin{tabular}{|c|c|c|c|c|c|c|c|c|}
\hline \multirow{8}{*}{ B } & 1 & 6.7 & 10.1 & 4.4 & 2.8 & 2.5 & 1.9 & 1.6 \\
\hline & 2 & 4.0 & 2.6 & 13.2 & 3.8 & 10.4 & 1.7 & 19.7 \\
\hline & 3 & 5.8 & 6.3 & 6.8 & 5.7 & 6.1 & 7.0 & 14.5 \\
\hline & 4 & 2.6 & 7.3 & 11.3 & 2.5 & 2.1 & 2.0 & 17.4 \\
\hline & 5 & 3.8 & 4.2 & 3.9 & 6.0 & 1.0 & 1.5 & 5.2 \\
\hline & 6 & 8.0 & 1.0 & 13.5 & 4.8 & 5.1 & 4.2 & 4.6 \\
\hline & 7 & 4.6 & 2.0 & 3.6 & 1.6 & 1.0 & 5.3 & -0.3 \\
\hline & Mean & $5.1 \pm 1.9$ & 4.8 & 8.1 & 3.9 & 4.0 & 3.4 & $9.0 \pm 8.1$ \\
\hline \multirow{3}{*}{ C } & 1 & 12.9 & 11.8 & 35.0 & 16.6 & 23.8 & 10.0 & 58.5 \\
\hline & 2 & 12.4 & 19.2 & 24.6 & 19.3 & 5.2 & 19.4 & 50.5 \\
\hline & Mean & 12.7 & 15.5 & 29.8 & 18.0 & 14.5 & 14.7 & 54.5 \\
\hline \multirow{4}{*}{$\mathrm{D}$} & 1 & 4.9 & 5.5 & 10.8 & 12.3 & 32.2 & 5.4 & 51.5 \\
\hline & 2 & 11.0 & 45.6 & 8.8 & 5.0 & 2.5 & 11.0 & 39.9 \\
\hline & 3 & 12.0 & 20.2 & 16.3 & 7.5 & 5.6 & 14.8 & 28.4 \\
\hline & Mean & 9.3 & 23.8 & 12.0 & 8.3 & 13.4 & 10.4 & 40.0 \\
\hline \multirow{7}{*}{$\mathrm{E}$} & 1 & 13.0 & 19.3 & 9.5 & 12.7 & 19.2 & 19.2 & 40.9 \\
\hline & 2 & 7.3 & 9.0 & 27.4 & 21.8 & 11.1 & 10.6 & 58.0 \\
\hline & 3 & 10.0 & 25.6 & 25.7 & 8.9 & 6.0 & 16.9 & 53.1 \\
\hline & 4 & 8.4 & 6.6 & 30.1 & 13.0 & 15.0 & 17.2 & 56.7 \\
\hline & 5 & 1.9 & 16.3 & 12.0 & 8.3 & 3.5 & 5.6 & 40.0 \\
\hline & 6 & 9.3 & 26.3 & 11.5 & 10.2 & 8.3 & 12.1 & 40.5 \\
\hline & Mean & 8.3 & 17.2 & 19.4 & 12.5 & 10.5 & 13.6 & 48.2 \\
\hline \multirow{7}{*}{$\mathrm{F}$} & 1 & 2.5 & 3.6 & 1.8 & 3.8 & 1.6 & 4.9 & 8.2 \\
\hline & 2 & 7.0 & 8.9 & 7.2 & 3.0 & 3.0 & 13.6 & 14.7 \\
\hline & 3 & 9.6 & 5.6 & 4.0 & 6.4 & 4.5 & 10.5 & 2.2 \\
\hline & 4 & 7.0 & 6.7 & 2.6 & 7.0 & 3.5 & 6.4 & 5.2 \\
\hline & 5 & 7.6 & 8.7 & 14.3 & 5.3 & 3.5 & 8.1 & 17.1 \\
\hline & 6 & 11.5 & 11.5 & 19.7 & 6.6 & 3.5 & 10.7 & 17.5 \\
\hline & Mean & 7.5 & 7.5 & 8.3 & 5.4 & 3.3 & 9.0 & 10.8 \\
\hline \multirow{3}{*}{ G } & 1 & 3.3 & 10.3 & 9.0 & 4.7 & 3.7 & 16.5 & 34.3 \\
\hline & 2 & 7.1 & 21.3 & 13.6 & 8.1 & 2.0 & 4.3 & 28.0 \\
\hline & Mean & 5.2 & 15.8 & 11.3 & 6.4 & 2.9 & 10.4 & 31.2 \\
\hline $\mathrm{H}$ & 1 & 8.9 & 16.0 & 4.7 & 5.5 & 3.6 & 6.5 & 9.6 \\
\hline \multirow{4}{*}{ I } & 1 & 9.0 & 6.4 & $6 \cdot 3$ & 4.6 & 6.1 & 10.0 & 6.4 \\
\hline & 2 & 17.3 & 30.6 & 13.6 & 6.0 & 3.7 & 13.0 & 15.0 \\
\hline & 3 & 16.7 & 15.1 & 16.7 & 29.7 & 6.3 & 12.0 & 29.7 \\
\hline & Mean & 14.3 & 17.4 & 12.2 & 13.4 & 5.4 & 11.7 & 17.0 \\
\hline
\end{tabular}




\begin{tabular}{|c|c|c|c|c|c|c|c|c|}
\hline \multirow[t]{2}{*}{$\mathrm{J}$} & $\begin{array}{r}1 \\
2 \\
3 \\
4 \\
5 \\
6 \\
7 \\
8 \\
9 \\
10 \\
11\end{array}$ & $\begin{array}{r}6.2 \\
2.9 \\
3.0 \\
10.2 \\
6.1 \\
6.2 \\
9.4 \\
10.6 \\
6.4 \\
10.9 \\
10.9\end{array}$ & $\begin{array}{r}25.6 \\
5.0 \\
8.8 \\
10.5 \\
10.2 \\
14.8 \\
20.2 \\
17.0 \\
15.2 \\
22.6 \\
28.2\end{array}$ & $\begin{array}{r}11.2 \\
27.3 \\
1.8 \\
18.0 \\
10.4 \\
15.0 \\
28.3 \\
10.2 \\
14.6 \\
12.3 \\
20.4\end{array}$ & $\begin{array}{r}10.8 \\
21.2 \\
4.8 \\
7.9 \\
4.4 \\
9.5 \\
17.0 \\
8.4 \\
9.0 \\
7.0 \\
16.0\end{array}$ & $\begin{array}{r}4.7 \\
9.6 \\
4.8 \\
6.3 \\
2.7 \\
4.8 \\
2.0 \\
8.0 \\
5.2 \\
8.0 \\
14.3\end{array}$ & $\begin{array}{r}11.4 \\
16.6 \\
7.7 \\
7.5 \\
8.5 \\
11.8 \\
10.0 \\
6.8 \\
2.9 \\
20.2 \\
12.0\end{array}$ & $\begin{array}{l}45.1 \\
71.0 \\
18.9 \\
19.6 \\
17.9 \\
37.3 \\
49.3 \\
18.6 \\
27.7 \\
37.4 \\
58.2\end{array}$ \\
\hline & Mean & $7.5 \pm 3.0$ & 16.2 & 15.4 & 10.5 & 6.4 & 10.5 & $36.5 \pm 18.0$ \\
\hline \multirow[t]{2}{*}{ K } & $\begin{array}{r}1 \\
2 \\
3 \\
4 \\
5 \\
6 \\
7 \\
8 \\
9 \\
10 \\
11 \\
12\end{array}$ & $\begin{array}{r}9.5 \\
5.6 \\
13.6 \\
8.7 \\
13.5 \\
10.0 \\
16.0 \\
8.8 \\
15.8 \\
10.4 \\
9.0 \\
7.1\end{array}$ & $\begin{array}{r}19.5 \\
5.1 \\
9.9 \\
13.8 \\
11.7 \\
8.1 \\
28.3 \\
7.4 \\
7.5 \\
9.2 \\
10.0 \\
10.0\end{array}$ & $\begin{array}{r}6.6 \\
13.0 \\
11.5 \\
10.6 \\
12.1 \\
17.0 \\
33.7 \\
7.1 \\
8.2 \\
17.4 \\
7.1 \\
11.2\end{array}$ & $\begin{array}{r}6.5 \\
5.2 \\
17.0 \\
16.5 \\
9.6 \\
4.0 \\
7.5 \\
6.7 \\
26.6 \\
9.1 \\
5.5 \\
5.2\end{array}$ & $\begin{array}{r}6.3 \\
5.5 \\
3.7 \\
0.4 \\
1.8 \\
1.9 \\
3.3 \\
6.9 \\
15.0 \\
2.1 \\
6.0 \\
1.3\end{array}$ & $\begin{array}{r}17.5 \\
5.6 \\
14.8 \\
6.9 \\
15.7 \\
9.0 \\
15.3 \\
9.0 \\
17.1 \\
6.0 \\
11.6 \\
8.1\end{array}$ & $\begin{array}{l}27.9 \\
17.6 \\
16.1 \\
22.1 \\
10.4 \\
10.0 \\
40.1 \\
10.7 \\
27.0 \\
12.6 \\
13.2 \\
14.5\end{array}$ \\
\hline & Mean & $10.7 \pm 3.3$ & 11.7 & 13.0 & 10.0 & 4.5 & 11.4 & $18.5 \pm 9.2$ \\
\hline
\end{tabular}

Fig. 3. Basiclevel of Urinary 17-OHCS

\begin{tabular}{|c|c|c|c|c|c|}
\hline Tumo2 & \multicolumn{3}{|c|}{$\begin{array}{l}\text { Basic Level } \\
123456789 \\
\end{array}$} & \multicolumn{2}{|c|}{ 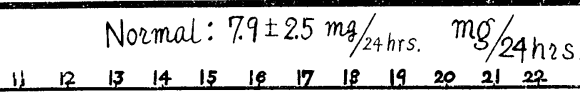 } \\
\hline Pituitary & $\bullet \quad \bullet$ & $\bullet$ & $\infty+\infty$ & $\bullet$ & $\bullet$ \\
\hline Cranioph. & - $\quad \bullet$ & - $\bullet$ & b & & \\
\hline Postsellar & & & & $\cdots$ & \\
\hline Frontal & $\bullet$ & $\bullet$ & $p \cdot \bullet$ & $\bullet$ & \\
\hline MiddleCran & - & & & - $\bullet$ & \\
\hline III-Ventr. & & & • & & \\
\hline Parietoocci. & $\bullet$ & $: 0$ & $\bullet$ & $\bullet$ & \\
\hline Pinealoma & • & $\bullet$ & & & \\
\hline Cerebellar & & :- & $\bullet$ & & \\
\hline $\begin{array}{l}\text { Cerebello-io- } \\
\text { pontine-Ang. }\end{array}$ & & & $\because \bullet \bullet$ & $\because$ & $\because$ \\
\hline Brai-stem & & & - & & $\bullet$ \\
\hline
\end{tabular}

アリンジオーマの症例 7 例では平均 $5.1 \mathrm{mg} /$ 日で, 対照より低く, 分散は小であつた。前頭葉腫瘍, 頭頂後

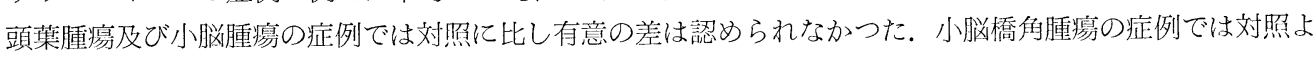


りやや高值を示し，少数例であるが，鞍後部腫瘍，中頭蓋窩腫瘍，及び脳幹部腄瘍の症例においても対照に 比べてやや高い傾向を示した (Table 4, Fig. 3).

脳春喵液圧, 病歴と基礎排泄量との関係を検討した。まず基礎排泄量と脳脊髄液圧とは特に相関が認めら れなかつた．次に基礎排泄量と発症よりの期間，即ち病歴の長さとは何れの腫湯群についても相関々係を見 出し得なかつた。

\section{B. ACTH-Z テスト}

Table 5. Peak-Elevation in ACTH-Z-test (No. of Cases)

\begin{tabular}{|c|c|c|c|c|}
\hline $\begin{array}{l}\text { Peak-Elevation } \\
\text { Case of Tumor }\end{array}$ & I & II & III & IV \\
\hline A. Pituitary-Tumor & 3 & 10 & 3 & \\
\hline B. Craniopharyngioma & 1 & 5 & 1 & \\
\hline C. Postsellar Tumor & $\zeta$ & 2 & 1 & \\
\hline $\begin{array}{l}\text { D. T. in Middle Cran. } \\
\text { Fossa }\end{array}$ & 2 & / & ' & 1 \\
\hline E. Frontal-Tumor & 3 & 3 & $\zeta$ & \\
\hline F. Parieto-occipital-T. & 1 & 2 & 3 & \\
\hline G. Pinealoma & 2 & $\zeta$ & $\zeta$ & \\
\hline H. T. in III-Ventuicle & 1 & $\zeta$ & $\zeta$ & \\
\hline I. T. in Brain-stem & 2 & $\zeta$ & 1 & \\
\hline J. Gerebellar Tumor & 6 & 5 & $\zeta$ & \\
\hline $\begin{array}{l}\text { K. Cerebello Pontine } \\
\text { Angle T. }\end{array}$ & 3 & 5 & 2 & \\
\hline Control & 15 & 9 & 1 & 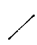 \\
\hline Pulmonary tbc. & 8 & 1 & 1 & \\
\hline
\end{tabular}

Fig. 5 ACTH-Z-test in Cerebral Tumor Cases

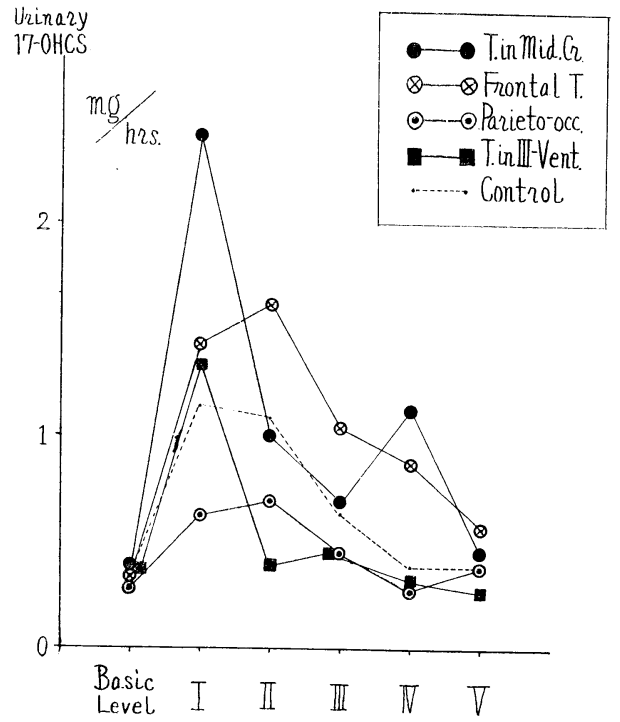

Fig. 4 ACTH-Z-test in Sellar \& Parasellar Tumor Cases

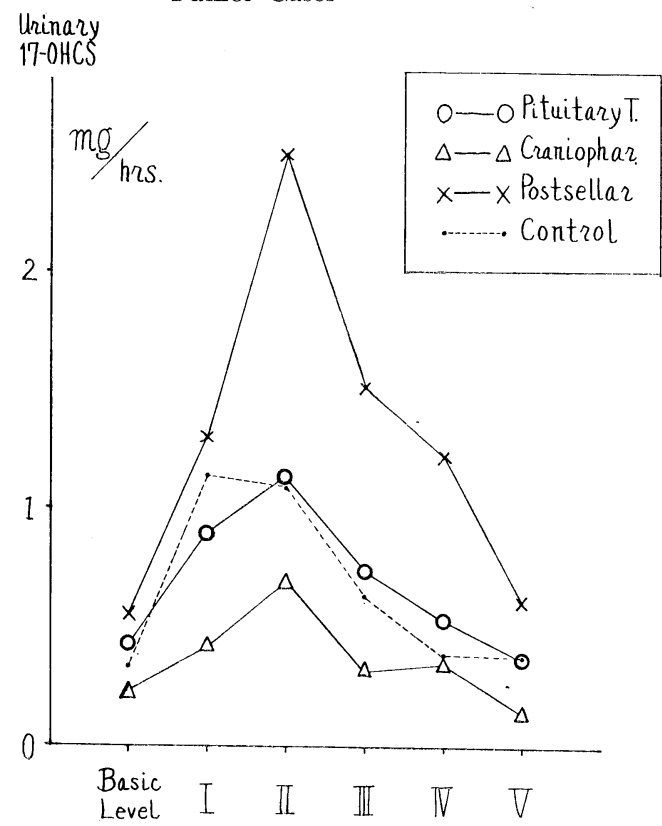

Fig. 6 ACTH-Z-test in Cases with Tumors in Posterior Cranial Fossa

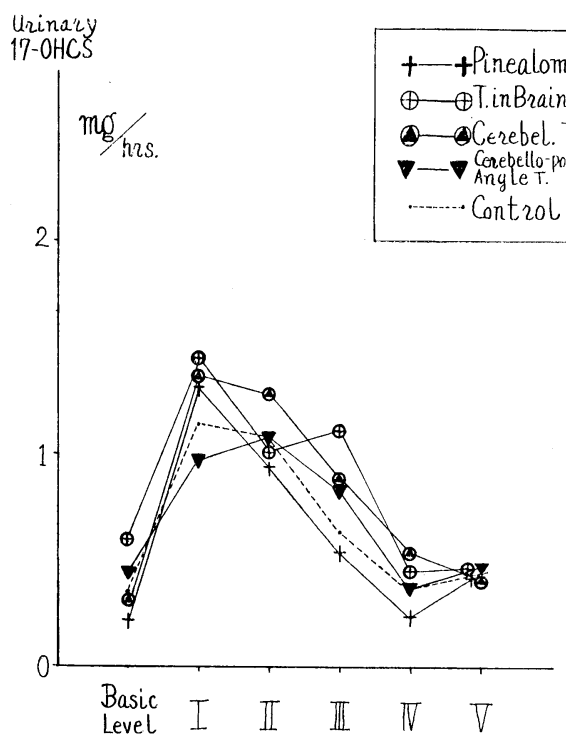




\section{ACTH-Z 負荷後の尿中総 $17-\mathrm{OHCS}$ 排泄量の変動}

a. 対照例

対照例及び軽症肺結核症例の ACTH-Z テストにおいて最大排泄量は大多数が I 又は II 認められた.

(Table 2, 3, 5)

\section{b. 脳腫瘍症例}

脳下垂体腫瘍, クラニオファリンジ オーマ, 頭頂後頭葉腫湯, 及び小脳橋 角腫瘍の症例では最大排泄量は II, III に多く認められ，AGTH-Z テストに おける反応が対照に比べて12〜24時間 遅政する事を示している. (Table 4,5)

(Fig. 4, 5, 6)

\section{2. 負荷反応量 \\ a. 対照例}

対照例では $11.0 \sim 41.2 \mathrm{mg}$ の範囲に 分布し, 平均值 $24.8 \pm 8.6 \mathrm{mg}$ であつ た. 又肺結核症例の負荷反応量は 12.3 〜 40.4mgの範囲に分布し, 平均值は $25.3 \pm 9.0 \mathrm{mg}$ であつた. (Table 2,3) これ等の間には有意の差は認められな かつた.
Table 6. Analysis of Responses in ACTH-Z-test (No. of Cases)

\begin{tabular}{|c|c|c|c|}
\hline Case of Tumor & $\begin{array}{l}\text { Hyper- } \\
\text { reactive }\end{array}$ & $\begin{array}{l}\text { Normo- } \\
\text { reactive }\end{array}$ & $\begin{array}{l}\text { Hypor- } \\
\text { eactive }\end{array}$ \\
\hline A. Pituitary-Tumor & 1 & 8 & 7 \\
\hline B. Craniopharyngiome & $\zeta$ & 3 & 4 \\
\hline C. Postsellar Tumor & 2 & $\zeta$ & \\
\hline D. T. in Middle Cran. Fossa & 1 & 2 & $\zeta$ \\
\hline E. Frontal-Tumor & 3 & 3 & $\zeta$ \\
\hline F. Parieto-occspital-T. & / & 4 & 2 \\
\hline G. Pinealoma & $\zeta$ & 2 & $\zeta$ \\
\hline H. T. in III-Ventricle & & 1 & \\
\hline I. T. in Brain-stem & I & 2 & 1 \\
\hline J. Gerebellar Tumor & 4 & 7 & $\zeta$ \\
\hline K. Cerebello-pontine AngleT. & $\zeta$ & 12 & $\zeta$ \\
\hline Control & $\zeta$ & 25 & $\zeta$ \\
\hline Pulmonary Tbc. & $\zeta$ & 10 & 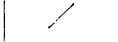 \\
\hline
\end{tabular}

Fig. 7 Adrenoeortico-sesponse to Corticotropin (Acr-C)

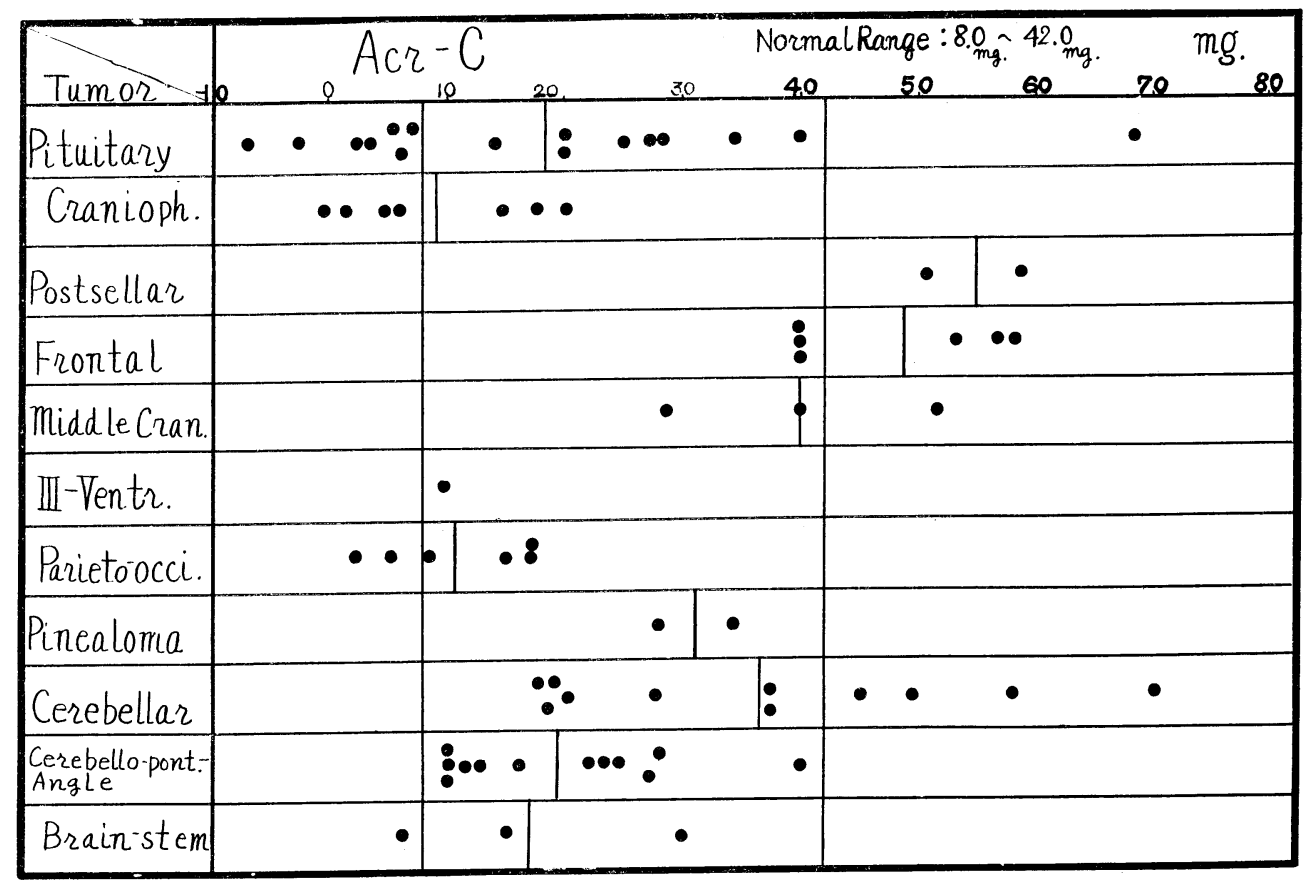


Fig. 8. Tumors in Posterior Cranial Fossa

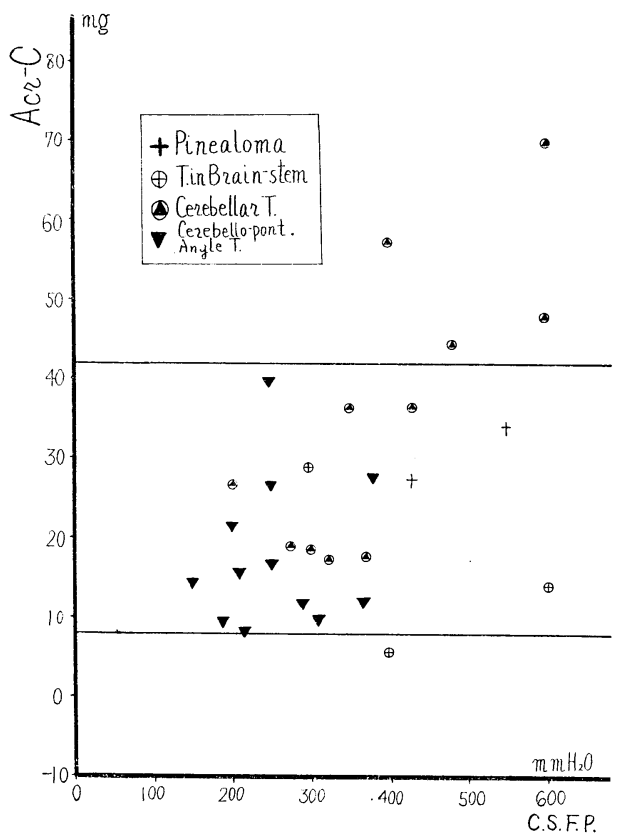

負荷反応量の正常範国を決定する為 $M_{ \pm} 2 \mathrm{u}$ を用い てその上下界を求めた。 即ち $\mathrm{M}+2 \mathrm{u}=42.0 \mathrm{mg}, \mathrm{M}-$ $2 \mathrm{u}=7.6 \mathrm{mg}$ であるから，著者は真荷反店量の正常範四 として，8.0〜 42.0 $\mathrm{mg}$ と規定し，乙の籁国に入るもの を正常反応 (Normoreactive Response), 42.0mg を 超えるものを高反応 (Hyperreactive Response), 8.0 mgより低いものを低反応 (Hyporeactive Response) とした．肺結核患者10例々ついて同様の範囲在求める と, $\mathrm{M}+2 \mathrm{u}=43.3 \mathrm{mg} . \mathrm{M}-2 \mathrm{u}=7.3 \mathrm{mg}$. となつた.

\section{b. 脳腫瘍例}

脳下垂体腫傷，クラニオファリンジオーマ及び頭頂 後頭葉腫揘の症例には低及忘が多く，䩲後部，中頭 蓋窝，前頭葉及び小脸腫煌症例には高反忘が多い。 (Table 6, Fig. 7)

次ぎに負荷反応量と脳零髄液厓との関係を見ると鞍 近傍腫瘍群及び大脳腫晹群に認むべき相関はなかつ た.内脳水腫を合併する腫湯群（Fig.8）では小脳腫 瘍症例の高反応を示すものは脳脊髄液が高い傾向をう かがう事が出来る。

負荷反応量と発症よりの期間即ち病歴の長さとの関 係をみると頭頂後頭葉腫瘍例（Fig.9）は病歴が長く，又すべて負荷反応量は低い．Fig. 10 は内脳水腫を伴 う腫瘍症例で，小脳腫瘍症例では高反応を示す症例は発症よりの期間か短い. 少なくとも小脳腫瘍症例に関
Fig. 9. Cerebral Tumors

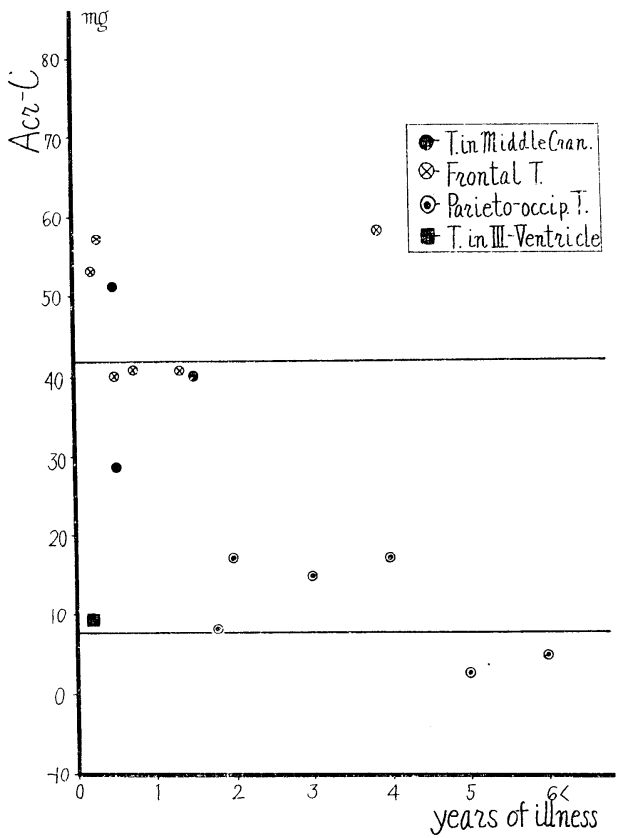

Fig. 10. Tumors in Posterior Cranial Fossa

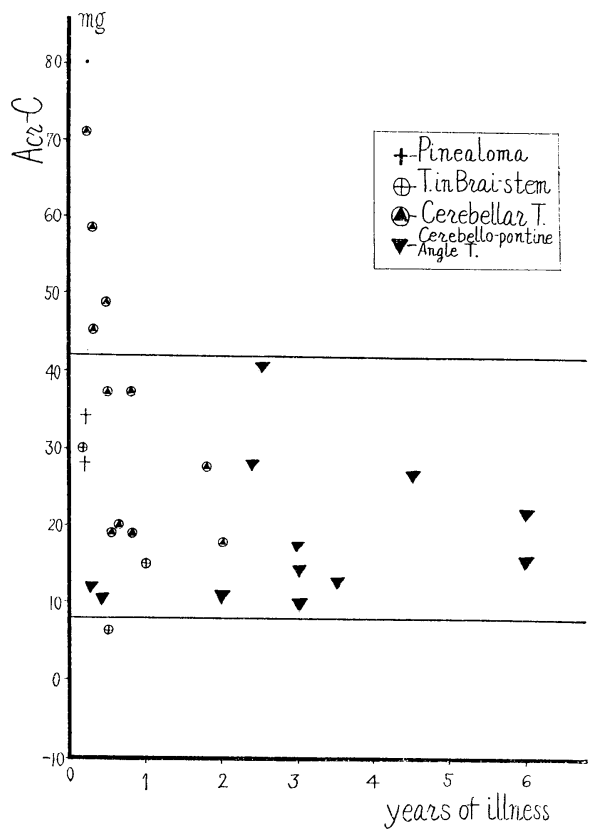




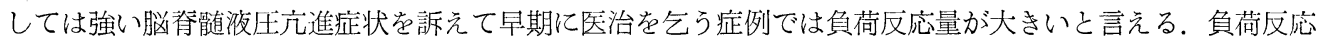
量と基礎排泄量との関係は各腫焬症例について何れも一定の関係を認め得なかつた。

\section{C. 手術に対する副腎皮質反応}

1. 排泄量増加分の変動

\section{a. 対照例（一側肺上葉切除例）}

対照10例について術当日〜術後7 日目迄の各日の尿中総 17-OHCS 排泄量汃ら基礎排泄量を差引いた値, 即ち尿中総 17-OHCS 排泄量の増加分は Table 7 の如くである. 即ち10例中 8 例が術後 1 日目に最大排泄

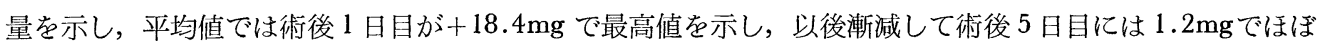
基礎排泄量に等しくなつた。(Fig.11)

Table-7 Adrenocortico-response in Cases of Upper Lobectomy

(Urinary total 17-OHCS increased from Basic Level, mg/24hrs.)

\begin{tabular}{|c|c|c|c|c|c|c|c|c|c|c|c|}
\hline \multirow{2}{*}{ Case } & \multirow{2}{*}{ OP. } & \multicolumn{7}{|c|}{ Postoperative Days } & \multirow{2}{*}{ Acr.-O } & \multirow{2}{*}{ Acr-G } & \multirow{2}{*}{ Acr-I } \\
\hline & & 1 & 2 & 3 & 4 & 5 & 6 & 7 & & & \\
\hline 1 & +2.1 & +5.2 & +21.7 & +1.9 & +1.0 & +7.1 & $1+1.7$ & -1.1 & 39.6 & 24.8 & 1.6 \\
\hline 2 & +3.0 & +13.5 & +2.3 & -1.3 & $3+3.1$ & +1.2 & $2+0.2$ & -0.9 & 21.1 & 17.3 & 1.2 \\
\hline 3 & +8.9 & +22.5 & +16.0 & +13.7 & $7+4.6$ & -2.9 & $9-1.1$ & +4.1 & 71.9 & 35.6 & 2.0 \\
\hline 4 & +1.0 & +21.8 & +13.3 & +20.8 & $3+8.9$ & +4.9 & $9+2.8$ & +3.0 & 76.5 & 34.6 & 2.2 \\
\hline 5 & +4.0 & +25.6 & +17.7 & +2.8 & $3+9.5$ & +0.5 & $5+2.6$ & 0 & 62.7 & 40.4 & 1.6 \\
\hline 6 & +4.3 & +8.5 & +21.6 & +2.3 & $3+1.4$ & -0.7 & $7 \mid-2.6$ & -2.6 & 32.2 & 20.1 & 1.6 \\
\hline 7 & +4.1 & +19.0 & +14.9 & +9.2 & +9.8 & +2.0 & +0.3 & -0.2 & 59.1 & 19.2 & 3.1 \\
\hline 8 & +6.8 & +24.6 & +5.4 & 0 & +2.9 & -1.3 & $3-8 \cdot 0$ & -3.3 & 27.1 & 23.8 & 1.1 \\
\hline 9 & +3.4 & +30.6 & +16.7 & +6.6 & +15.8 & +1.0 & -5.1 & -4.0 & 65.0 & 25.0 & 2.6 \\
\hline 10 & +6.2 & +12.5 & +1.2 & +6.2 & -2.0 & +0.1 & -1.9 & -2.8 & 19.5 & 12.3 & 1.6 \\
\hline Mean & \begin{tabular}{|l|}
$+\quad 4.4$ \\
\pm \\
\pm
\end{tabular} & $\begin{array}{r}+18.4 \\
+\quad 8.2 \\
\end{array}$ & $\begin{array}{r}13.1 \\
\pm 7.5\end{array}$ & $\begin{array}{l}+6.2 \\
\pm 6.8\end{array}$ & $\left|\begin{array}{r}5.5 \\
\pm 5.4\end{array}\right|$ & $\begin{array}{r}+1.2 \\
\pm \quad 2.9 \\
\end{array}$ & $\left|\begin{array}{l}-1.1 \\
\pm\end{array}\right|$ & $\begin{array}{r}-0.8 \\
\pm \quad 2.6 \\
\end{array}$ & $\begin{array}{r}42.5 \\
+22.5 \\
\end{array}$ & $\begin{array}{r}25.3 \\
+\quad 9.0\end{array}$ & $\begin{array}{r}1.9 \\
+0.6 \\
\end{array}$ \\
\hline
\end{tabular}

\section{b. 脳腫瘍手術例 (Table 8, 9)}

合併症の無かつた脳腫㐭手術例39例の中，常温下普通麻酔群17例では排泄量増加分で最大となるのは12例 までが術後 1 日目で, 平均值では $+28.6 \mathrm{mg}$, 以後漸減して術後 7 日目ではなお+7.6mg であつた。乙れに 反して人工冬眠群 22 例では術後 1 日目の排泄量增加分は非常に低く, $+6.0 \mathrm{mg}$ 亿過ぎない. 術後第 2 日目及 び第 3 日目には $+14.5,+18.7 \mathrm{mg}$ と增加するが, 術後第 3 日目を頂点とするものは 22 例中 13 例で, 以後急 速に減少して術後 7 日目には基礎排泄量に復した。即ち人工冬眠群では術当日及び術後 1 日目には脳下垂体

Table 8. Adrenocortico-response to Brain Tumor Operations under Normothermic Anesthesia

(Urinary total 17-OHCS increased from Basic Level, mg/24hrs.)

\begin{tabular}{|c|c|c|c|c|c|c|c|c|c|c|c|}
\hline \multirow{2}{*}{ Case } & \multirow{2}{*}{ OP. } & \multicolumn{7}{|c|}{ Postoperative days } & \multirow{2}{*}{ Acr-O } & \multirow{2}{*}{ Acr-G } & \multirow{2}{*}{ Acr-I } \\
\hline & & 1 & 2 & 3 & 4 & 5 & 6 & 7 & & & \\
\hline$A-10$ & +36.8 & +62 . & +67.8 & +17 & +31 & +6 & +5 & +2.2 & 231.6 & 24.7 & 9.5 \\
\hline$A-15$ & +70.8 & +53 . & +77.5 & +28 & +13 . & +9 & +14 & +11.4 & 279.4 & 68.4 & 4.1 \\
\hline$B-2$ & 0 & -0 . & +15.6 & +10 & +5 . & +6 & +12 & +2.2 & 50.9 & 19.7 & 2.5 \\
\hline$B-5$ & +1.2 & & +23.7 & +12 & & & +10 & +6.5 & 66.7 & 5.2 & 12.8 \\
\hline
\end{tabular}




\begin{tabular}{|c|c|c|c|c|}
\hline B- 1 & $|-5.1|+2.5-3.4|+13.7|+2.5+2.6|-4.0-3.9|$ & 4.9 & 1.6 & 3.0 \\
\hline $\mathrm{D}-2$ & $+5.6+36.2+22.9+20.4+4.3+2.6+28.5+8.4$ & 128.9 & 39.9 & 3.2 \\
\hline $\mathrm{E}-2$ & $+14.4+40.8+30.8+16.3+3.5+27.3+9.4+18.3$ & 160.8 & 58.0 & 2.8 \\
\hline $\mathrm{E}-5$ & $+18.5+50.5+14.5+37.7+18.5+26.5+24.9+16.5$ & 207.6 & 40.0 & 5.2 \\
\hline $\mathrm{E}-6$ & $+20.1+40.5+7.3+14.5+17.0+25.8+16.7+5.7$ & 147.6 & 40.5 & 3.6 \\
\hline $\mathrm{F}-6$ & $-4.1+18.9+14.7+8.7+0.7+3.8+4.6+6.4$ & 53.7 & 17.5 & 3.7 \\
\hline $\mathrm{J}-4$ & $+17.6+24.8-7.5+7.7+1.6-8.3+3.3-0.2$ & 39.0 & 19.6 & 2.0 \\
\hline $\mathrm{J}-5$ & $+3.9+15.6+9.7+7.0+12.0+1.0+0.2+4.8$ & 54.2 & 17.9 & 3.0 \\
\hline $\mathrm{J}-6$ & $+8.6+42.2+11.7+6.4+49.8+20.7+13.9+20.2$ & 173.5 & 37.3 & 4.6 \\
\hline $\mathrm{J}-8$ & $+12.3+39.0+1.7+8.0+17.5+9.7+13.3+8.1$ & 109.6 & 18.6 & 5.9 \\
\hline $\mathrm{J}-9$ & $+1.9+17.5+21.7+18.0+6.0+3.5+20.5+5.0$ & 94.1 & 27.7 & 3.4 \\
\hline$I-1$ & $+4.0+14.8+2.2+12.2+8.0+7.8+6.6+5.2$ & 57.6 & 6.4 & 9.0 \\
\hline $\mathrm{K}-2$ & $+11.6+26.6+25.5+35.9+18.6+22.2+9.3+12.2$ & 161.9 & 17.6 & 9.2 \\
\hline Mean & $|+12.8+28.6+19.8+16.2+12.7+10.2|+11.2 \mid+7.6$ & $\begin{array}{l}18.9 \\
\pm 76.4\end{array}$ & 7.1 & 1 \\
\hline
\end{tabular}

Table 9. Adrenocortico-response to Brain Tumor Operations under Artificial Hibernation (Urinary total 17-OHCS increased from Brsic Level, mg/24hrs.)

\begin{tabular}{|c|c|c|c|c|c|c|c|c|c|c|c|}
\hline \multirow{2}{*}{ Case } & \multirow{2}{*}{ OP. } & \multicolumn{7}{|c|}{ Postoperative Days } & \multirow{2}{*}{ Acr-O } & \multirow{2}{*}{ Acr-C } & \multirow{2}{*}{ Acr-I } \\
\hline & & 1 & 2 & 3 & 4 & 5 & 6 & 7 & & & \\
\hline$A-5$ & +1.7 & +6.1 & +4.9 & +25.1 & +11.7 & $7-2.9$ & +1.5 & $5-2.5$ & 45.6 & 34.4 & 1.1 \\
\hline$A-9$ & +3.5 & -10.7 & +0.3 & +27.0 & +10.0 & $0+11.0$ & -10.9 & $9-5.0$ & 25.2 & 27.4 & 0.9 \\
\hline $\mathrm{J}-7$ & +4.4 & +6.6 & +13.7 & +15.8 & +2.8 & $3+0.7$ & -1.2 & $2-1.4$ & 41.4 & 49.3 & 0.8 \\
\hline $\mathrm{K}-7$ & +1.1 & +7.3 & +13.9 & +4.4 & +4.7 & $7-2.0$ & -3.4 & $4-1.4$ & 24.4 & 40.1 & 0.6 \\
\hline $\mathrm{C}-2$ & -0.8 & -4.2 & +3.3 & +13.1 . & -1.5 & $5+13.6$ & +7.8 & $3+1.3$ & 31.9 & 50.2 & 0.6 \\
\hline$D-3$ & -7.3 & +1.7 & +9.8 & +1.3. & +14.9 & $9+9.3$ & +4.7 & $7-6.0$ & 28.4 & 28.4 & 1.0 \\
\hline$E-1$ & 0 & +6.8 & +16.3 & +30.3 & +11.7 & $7+7.5$ & +0.8 & $3-3.5$ & 69.9 & 40.9 & 1.7 \\
\hline$E-3$ & -0.2 & +5.4 & +12.4 & +26.2 & +14.5 & $\overline{5}+10.2$ & +7.4 & $4-2.0$ & 73.9 & 53.1 & 1.4 \\
\hline$F-1$ & +1.1 & +6.8 & +8.6 & +2.5 & +4.1 & $1+1.5$ & 0 & 0 & 24.6 & 8.2 & 3.0 \\
\hline$G-2$ & +2.2 & +7.8 & +4.4 & +24.0 & +10.0 & +6.4 & +2.8 & $3+4.2$ & 61.8 & 28.0 & 2.2 \\
\hline$I-3$ & -1.5 & +9.3 & +29.2 & +8.5 & +1.4 & $4-6.5$ & -8.4 & $4-9.3$ & 22.7 & 29.7 & 0.8 \\
\hline$J-3$ & +3.7 & +6.5 & +8.4 & +2.6 & +1.0 & +2.9 & +2.7 & $7+0.6$ & 28.4 & 18.9 & 1.5 \\
\hline $\mathrm{J}-10$ & +4.3 & +10.5 & +9.9 & +27.3 & +18.5 & $5+4.7$ & -1.5 & $5-2.7$ & 71.0 & 37.4 & 1.9 \\
\hline$J-11$ & -1.2 & +9.1 & +27.2 & +20.4 & +15.1 & $1+14.0$ & +1.1 & $1-2.9$ & 82.8 & 58.2 & 1.4 \\
\hline $\mathrm{K}-1$ & -2.9 & -3.0 & +28.1 & +21.8 & +33.7 & $7+28.4$ & +10.4 & $4+11.3$ & 127.8 & 27.9 & 4.6 \\
\hline $\mathrm{K}-3$ & -0.2 & +2.1 & +30.6 & +28.8 & +44.6 & $5+19.8$ & +11.3 & $3+3.2$ & 140.2 & 16.1 & 8.7 \\
\hline $\mathrm{K}-4$ & +2.1 & +27.4 & +30.3 & +34.5 & +15.4 & $4+10.9$ & 0 & +3.2 & 123.8 & 22.1 & 5.6 \\
\hline $\mathrm{K}-5$ & -2.8 & +15.8 & +13.5 & +21.3 & +7.9 & $9-4.0$ & -0.6 & $5+1.7$ & 52.8 & 10.4 & 5.1 \\
\hline $\mathrm{K}-6$ & +0.2 & -3.5 & +33.5 & +10.9 & +6.4 & $4+12.2$ & +10.9 & $9-2.5$ & 68.1 & 10.0 & 6.8 \\
\hline$K-8$ & -0.8 & +7.9 & +3.7 & +23.2 & +7.0 & -2.8 & -2.6 & -4.8 & 30.8 & 10.7 & 2.9 \\
\hline $\mathrm{K}-11$ & +1.2 & +6.7 & +9.5 & +15.8 & +3.1 & $1+2.2$ & -1.9 & $9-1.0$ & 35.6 & 13.2 & 2.7 \\
\hline $\mathrm{K}-12$ & +0.5 & +10.3 & +6.9 & $\mid+27.2$ & +7.6 & $5+0.5$ & -3.9 & $9+3.1$ & 52.2 & 14.5 & 2.6 \\
\hline Mean & +0.4 & +6.0 & & \begin{tabular}{|}
+18.7 \\
\end{tabular} & $\mid+11.1$ & $1+6.3$ & +1.2 & $2+0.7$ & $\begin{array}{l}57.4 \\
\quad \pm 35.2 \\
\end{array}$ & $\begin{array}{r}28.6 \\
\pm 15.5 \\
\end{array}$ & $\begin{array}{r}2.6 \\
\quad \pm 2.2 \\
\end{array}$ \\
\hline
\end{tabular}


副腎皮質系の反応が抑制せられる傾向を示し, 術後第 3 日目には最大となるが常温下脳手術の約 $2 / 3$ 程度の

Fig. 11 Adrenocortico-response in Brain Tumor Operations (Urinary total 17-OHCS increased from Basic Level)

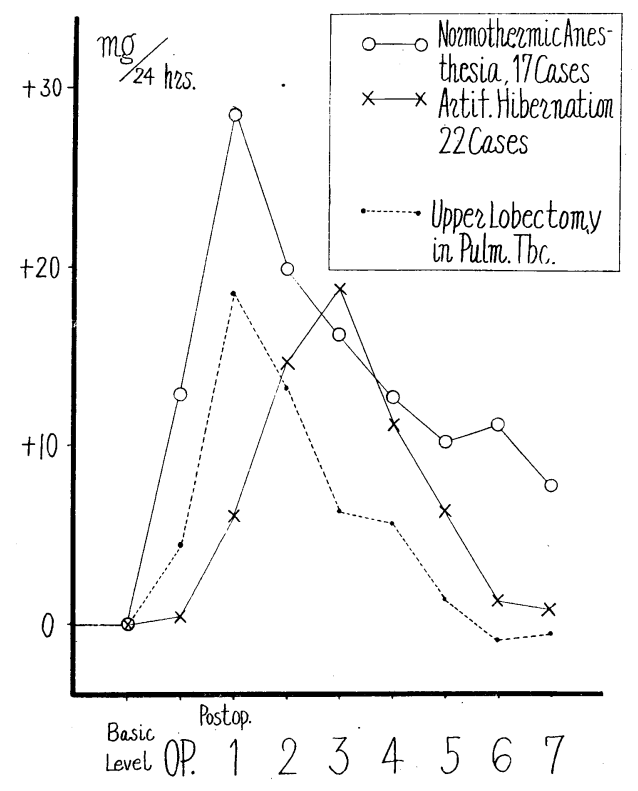

排泄量である。その後は急速に基礎排泄量に復して 行く傾向を示した. (Fig.11)

\section{2. 手術反応量}

\section{a. 対照例 (一側肺上葉切除例)}

対照例10例の手術反応量は $19.5 \mathrm{mg}$ から $76.5 \mathrm{mg}$ の 間に分布し，その平均值は $42.5 \pm 22.5 \mathrm{mg}$ であつた。 (Table 7)

\section{b. 脳腫瘍症例}

脳腫瘍手術の手術反応量は Table 8, 9, Fig. 12 の如くである. 即ち常温下普通麻酔例では手術反応 量は 4.9 279.4mg の広範囲に分布し，人工冬眠例 では22.7〜161.7mgの比較的狭い分布を示した.

\section{3. 麻酔と手術反応量の関係}

常温下普通麻酔例と人工冬眠例とを比較すると Table 8, Table 9 の如く, それぞれ手術反応量平

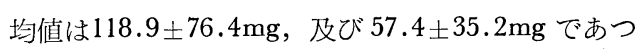
た. これ等 2 群の負荷反応量平均值は, それぞれ $27.1 \pm 19.0 \mathrm{mg}$ 及び $28.6 \pm 15.5 \mathrm{mg}$ でこの 2 つの值 の間には有意の差は認めない，従つて手術反応量か ら比較すれば，常温下普通麻酔群の手術侵襲は人工

Fig. 12 Adrenocortico-response to Operation (Acr-O)

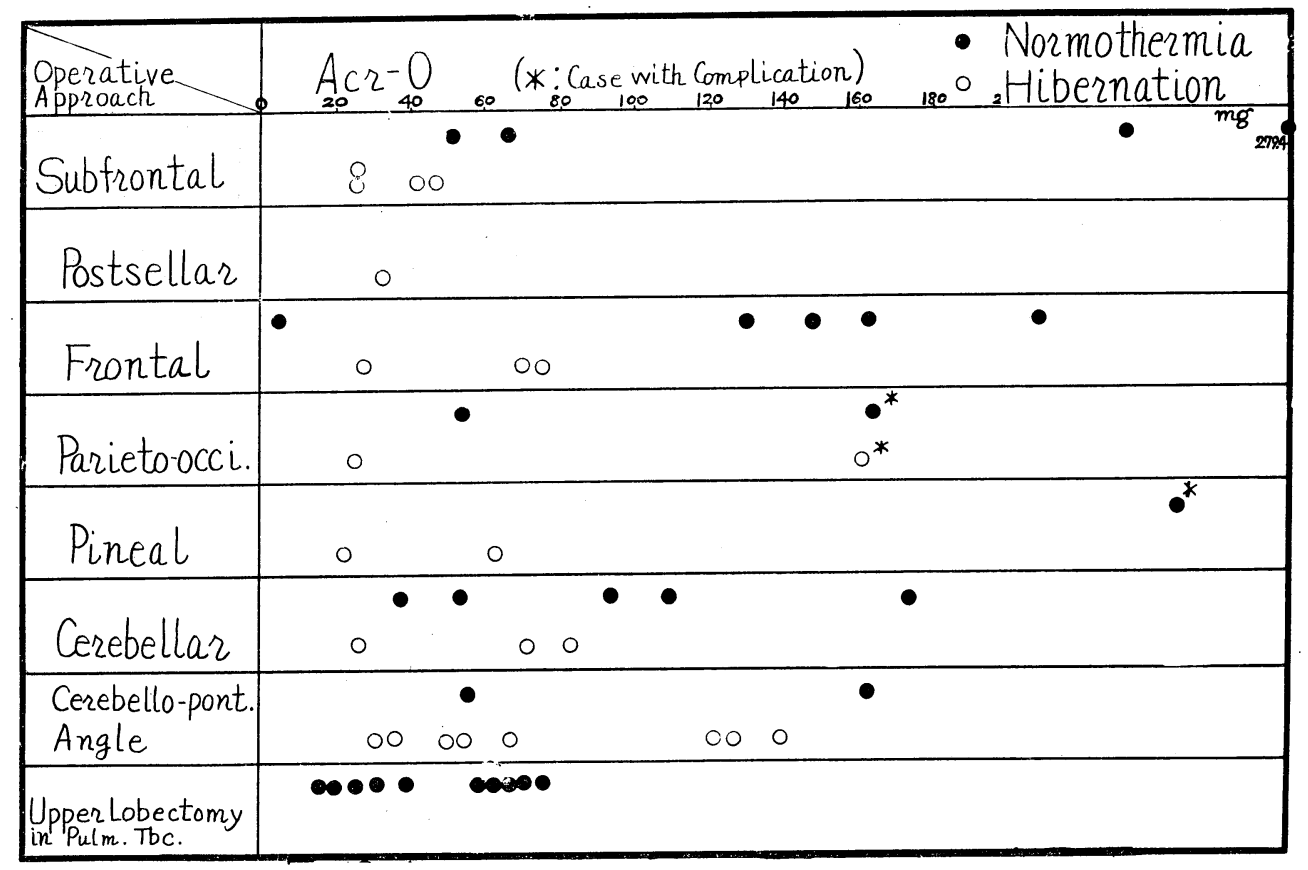


冬眠群のそれより大きいと言える。

4. 負荷反応量亡手術反応量との関係 ; 副腎皮質反応指数 (Adrenocortico-response-Index, Acr-1) の設定

一側肺上葉切除例につき, 負荷反応量と, 手術反応量の間の関係をみると Fig.13の如くで相関を認める. $(\mathrm{r}=+0.82)$

この関係を利用して, 術前の副腎皮質機能の相異なる群や症例の間でも, 脳腫韵手術の脳下垂体副腎皮質 系に及ぼす侵襲の大小を比較する為に，次式に示す如く手術反応量のその個体の負荷反応量に対する比率を 求め,「副腎皮質反応指数」と名づけた。

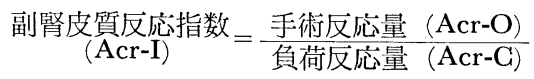

\section{b. 対照例 (一側肺上葉切除例)}

対照例の副腎皮質反応指数を示すと Table 7 の如くである. 即ち $1.1 \sim 3.1$ の間に分布し，その平均值は $1.9 \pm 0.6$ である.

\section{b. 脳腫瘍症例 (Table 8, 9, Fig.14)}

合併症の無かつた症例39例の副腎皮質反応指数を麻醉方法で分類すると Table 8, 9 の如くで常温下普通 麻酔例17例では2.5〜9.5の間に分布しその平均値は5.1〜3.1であつた。 人工冬眠例22例では0.6〜8.7の間に 分布しその平均値は $2.6 \pm 2.2$ であつた。各症例の負荷反応量を横軸に手術反応量を縦軸にとると Fig. 14 の 如く, 常温下手術例は縦軸に近く分布している. 人工冬眠例は 2 群に分かれ，1 群は常温下手術例とほぼ同 一傾向をとるものでこれは殆んど小脳橋角部手術例で，他の 1 群は横軸に近く分布している. 即ち小脳橋角 部手術例を除くと，人工冬眠施行例の副腎皮質反応指数は，常常温下普通麻酔例のそれよりも明らかに小で ある. 術中術後に合併症のあつた症，例即ちF-2，F-4及びI-2の副腎皮質反応指数はそれぞれ $11.0,31.4$ 及 び16.4で何れも他の症例に比べてかなり大きく, それぞれの群から较却し得る. こてで, 麻醉別に比較して 図示すると Fig.15の如くなる. 即5Oは人工冬眠例, は常温下普通麻醉例で, 各手術径路について, 合併 症のない症例では，人工冬眠例は常温下麻酹例よりも小さい值をとつている。脳下垂体副腎皮質系に及ぼす

Fig.13 Upper Lobectomy in Pulmonary Tbc.

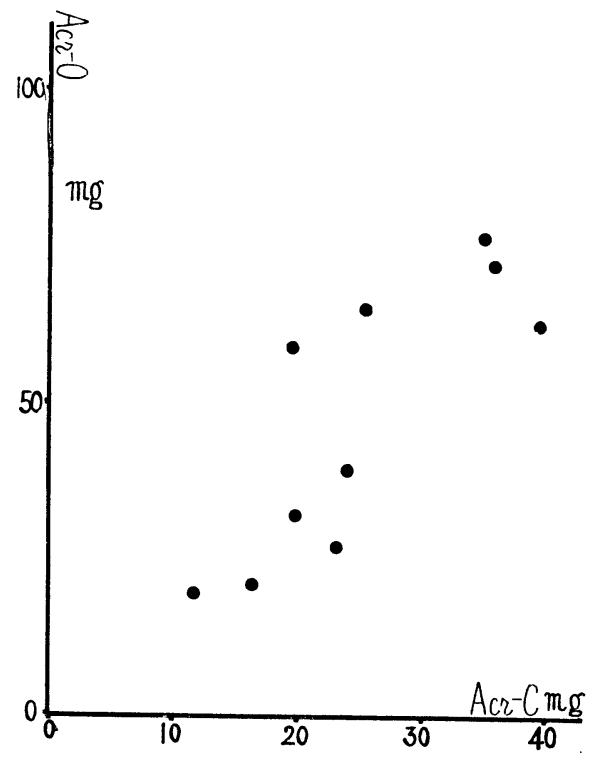

Fig. 14 Brain Tumor Operation

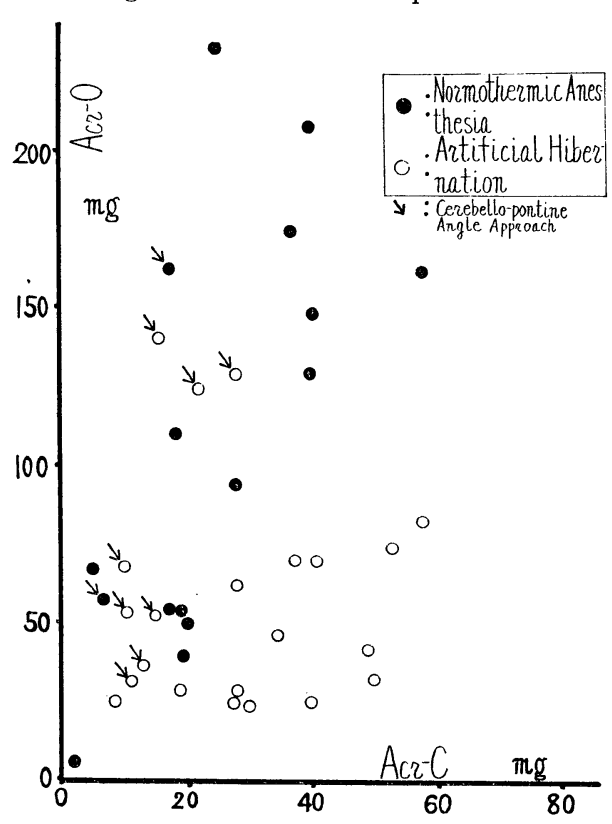


Fig. 15 Adrenocortico-response-Index (Acr-I)

\begin{tabular}{|c|c|}
\hline $\begin{array}{l}\text { Operative } \\
\text { Approach }\end{array}$ & 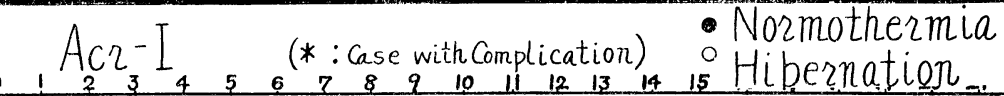 \\
\hline Subfrontal & $\begin{array}{lllll}0 & \bullet & \bullet & \bullet & \bullet \\
0 & & & \\
\end{array}$ \\
\hline Postsellar & 0 \\
\hline Frontal & $000 \quad \bullet$ \\
\hline Parietoocci. & $0^{\bullet}$ \\
\hline Pineal & $\circ \quad 0$ \\
\hline Cerebellar & $\begin{array}{l}\bullet \bullet \bullet \bullet \\
000\end{array}$ \\
\hline $\begin{array}{l}\text { Cerebello-pont. } \\
\text { Angle }\end{array}$ & $80 \quad 000 \quad 0 \quad 0^{\circ}$ \\
\hline $\begin{array}{l}\text { Upper Lobectomy } \\
\text { in Pulm.Tbc. }\end{array}$ & 008000 \\
\hline
\end{tabular}

侵襲の程度が人工冬眠例に於ては常温下普通麻酔例よりも小さいという傾向及び重症合併症を伴う症例では 大きいという傾向は，前頂の手術反応量の検討から推測されたがての副腎皮質反応指数を用いるとこれらの 傾向は更に明確となつた。

$$
\text { IV 考按 }
$$

\section{A. 副腎皮質機能検查法について}

1. ACTH-Z テストについて

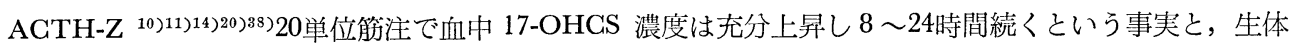
侵襲に対する副腎皮質反応のモデルとして本検査を行なうという観点からすれば AGTH に対する副腎皮 質反応は単に 17-OHCS の尿中排泄量増加のみならず基礎排泄量に復帰する迄の経過を追求すべきであると いう理由から著者は ACTH-Z テスト ${ }^{54)}$ を採用した.

\section{2. 負荷反応量について}

渡辺等の ACTH-Z テスト ${ }^{54}$ 原法では本法による副腎皮質反応をその反応様式の面から 3 型に分類してい ${ }^{26)}$ るが数量的に正常範囲を決定して居らなかつた。著者は此の正常範囲を明確にしようと考光，「負荷反応量」 を導入し, 正常範囲として8.0 42.0mg という值を求め得た。一定の ACTH 変動量に対し尿中 17-OHCS 排泄量が基礎排泄量からどれ程変動するかを量的に表現するのが予備能力の概念を端的に表現すると考えた からである. 此の様な概念はてれ迄数量的に明確化されていない25)26)ので著者は負荷反応量てついて正常範 囲を基準として低反応と高反応をも区分規定した. 大阪大学医学部附属病院中央臨床検査科で過去 5 力年間 に施行した諸種疾患例205例の ACTH-Z テストの成績 ${ }^{49}$ 亿ついて 負荷反応量を計算すると, 高反応を示す ものは僅かに 6 例に過ぎない．著者の成績では脳腫瘍患者66例中11例に高反応か認められた．此の事は中枢 神経系病変による下垂体副腎皮質系の変化は特異的な像を呈する事を示す. 高反応を示した11例中クッシン グ症候群類似の症状を呈したものはない.Schwartz ${ }^{47}$ )は ACTH を連続投与すると ACTH 亿対する副腎皮 


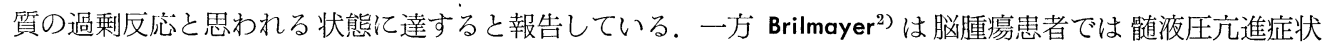
が始まつてから 6 週間以内では尿中 17-OHCS 排泄量が著明に高く此の時期はストレス状態にあると考えら れる成績を示している．乙の 2 つ成績から，脳腫瘍発生の初期には䯣液圧方進乃至はその他の原因により 或る期間に亘つて内因性 ACTH 放出が高度に持続される為，副婜皮質の AGTH に対する高度な反応性 が起つて来るのではないかと考光られる。てれ迄過剩反応として報告されているのはクッシング症候年群及 び妊娠例 5 の成績に過ぎず，もちろん脳腫瘍症例については報告はない．乙の高反応の臨床的意義を明らか にする様な症例を経験し得なかつた。一方低反応の症例14例中アヂソン氏病様の症状を示するものはなかつ たが，術後，副腎皮質不全性と思われるショックを1 例経験した。

\section{B. 脳腫瘍患者の副腎皮質機能について}

\section{1. 脳脊髄液圧に関する検討}

先ず基礎排泄量についてであるが Brilmayer ${ }^{2}$ の云う様な病歴と基礎排泄量との間の関連性を端的に解明

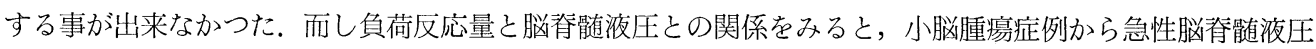
圥進は負荷反応量を増大せしめる傾向のある事をうかがう事が出来, 又頭頂後頭葉腫瘍症例から長期に亘る 慢性脳脊髄液圧九進は負荷反応量を減少せしめる傾向がある事をうかがい得た。

\section{2、脳腫瘍局在部位に関する検討}

脳下垂体腫瘍症例についてはてれ迄に二次的副腎皮質不全が報告されている，著者の症例でも低反応が多 くみられた。鞍上部腫瘍症例の副腎皮質機能については Brilmayer ${ }^{334)}$, Baur ${ }^{13)}$, Oppenheimer 及び Höckfelt ${ }^{19)}$ 等の報告がある。著者のクラニオファリンジオーマの症例においては負荷反応量の小さいものが多く分散も 小さいのでての腫場が AGTH 放出系を阻害する影響はむしろ脳下垂体腫湟より強いと考えられる.クラニ オファリンジオーマは脳下垂体, 視床下部の両方に年少の頃より長期に亘つて圧迫を及ぼしている為と考え られる. 7 例の自験例によれば B- 1, 2, 3,4 が鞍上部, B- 5, 6, 7 か鞍内, 鞍上両方にわたる症例である. 基礎排泄量では大差はないが，負荷反応量では後者は前者より低値を示す傾向を認める。乙れは Brilmayer ${ }^{33}$ の成績と一致する。乙の様な事実から脳下垂体及び 視床下部の両方に影響の及ぶ様な腫瘍の存在する時, 副腎皮質機能は強く抑制される事が推測される.

著者の脳下垂体腫場の例には高反応がみられた。一種の機能迁隹と考えられるが著者が既に発表した ${ }^{500}$ 如 く, 術前に高反応を示した脳下垂体腺腫症例も低反応を示した症例も，腫瘍を除去した後，約一年以内に何 れも正常範囲の負荷反応量を示すに到る。即ち脳下垂体腫漡は多くの場合はACTH 放出系に圧迫を及ぼし てその機能を低下せしめるが一部の症例では或る時期には逆に機能立進的に作用する事もあり何れにせよ腫 瘍の圧迫を除去すれば ACTH 放出系の機能は正常に復滞すると考えるのが妥当であろう。鞍後部腫瘍症例 2 例は基礎排泄量, 負荷反応量共に高值を示す。 2 例共トルコ鞍の破壊像は著明で, 又脳脊髄液圧は比較的 低く，病歷は $1 \sim 2$ 年であつた。鞍後部腫瘍症例の場合，高い負荷反応量を示す事実は特異な病態である. 前頭葉腫瘍及び中頭蓋窩腫瘍の症例で負荷反応量の高いものの多い事実は近年明らかになつた大脳辺縁系 ${ }^{30)}$ の下垂体に影響を及ぼす機構に対する腫場の直接間接の影響が考慮さるべきであると思われる．松果体腫瘍 症例は屡々内分泌症状を現わし, 副腎皮質機能々関しては三宅 ${ }^{31}$ 等の報告が見られ, 機能低下を報告するもの もある．著者の松果体腫湯の 2 症例は正常反応であつた．著者の症例で前頭葉腫瘍と頭頂後頭葉腫愓の症例 の間の負荷反応量の差異は臨床的に脳脊髄液圧や病歴の上にみられる差異や，辺縁系の影響以外に Edgahl7) やSetekleive ${ }^{46}$ )等の云う皮質の部位的差異が加わる可能性を否定し得ない.

以上の如く, 脳腫瘍症例においては䯙液圧允進, 病歴及び腫瘍の部位的差異等を通じて ACTH 放出系に 影響を与え，その結果副腎皮質反応を変化せしめると考えられる。

\section{C. 手術反応量について}

外科手術の生体に及ぽす影響を副緊皮質反応の面から追求し検討した報告は多( 15)16)17)18332)43(44)53).

而し脳外科方面では僅かに Fisher ${ }^{9)}$ 等の報告を見るに過ぎない. てれ迄の報告では多くは 17-OHCS の変 動経過の記述を行なつているに過ぎない故に経過全体の積分的な量的取扱い方が必要であると著者は考えた. 
この様な概念は Reece ${ }^{40}$ が既に示して居り，“4-Day Mean”と呼んでいる．著者は個体により基礎排泄量 にはかなり幅の差があるので, 各個体の基礎排泄量から手術により変動し再びその基礎排㳡量に復帰する過 程が量的に表現されねばならないという考えから, 術当日より術後 7 日目迄の尿中 17-OHCS 排泄量の基礎 排泄量よりの増加分の総和を求めて「手術反応量」とした.

この手術反応量と最大排泄量とを組合わせると一応，手術に対する副腎皮質反応の大きさと経過が端的に 量的に表現し得ると考える. 脳腫瘍手術例合併症の無い症例についてみると手術反応量の平均は常温下普通 麻酔群では $118.9 \pm 76.4 \mathrm{mg}$, 人工冬眠群では $57.4 \pm 35.2 \mathrm{mg}$ である。乙の 2 群の尿中 17-OHCS 排泄量の著 しい差は主に術後 1 日目及び 2 日目の排泄量の相違による. 故に術当日より術後 1 日目， 2 日目に施行され ている人工冬眠が下垂体副腎皮質反応を抑制していると思われる，我々の行なつた人工冬眠法 $\left.{ }^{233}{ }^{33}\right)^{513}$ は，表 面泠却による低体温法にかなりの量の遮断カクテル剤を併用している点に特長がある. 術中の維持直腸温は $28^{\circ} \mathrm{C} \sim 30^{\circ} \mathrm{C}$ であるが単純な浸漬法による低体温 ${ }^{8}$ ではこの温度では副腎静脈中 17-OHCS 分泌量は著明に減 少して居り，侵襲を加えても増加しない．所が ACTH に反応するので侵襲て対する ACTH の分泌が抑 制されていると考えられる，急速に復温すると直腸温 $30^{\circ} \mathrm{C}$ 付近よりすでに常温下安静時の血中 17-OHCS の 水準に近くなり，術後は通常の常温下手術の場合とほとんど同様な副腎皮質反応を来たすとされている．著 者は主として脳手術後の脳腫脹を防ぐ為に急速復温を避け, 調節しつつ緩徐に復温し, 直腸温度 $37^{\circ} \mathrm{C}$ 恢復す るのは術後平均48時間前後である. 所が石井 ${ }^{22}$ 等は脳腫瘍手術々後及び重症頭部外傷で過高熱，昏睡等に陥 つた患者に冷却を行ない遷延性冷却が却つて強い侵襲となると述べている．著者の成績では副腎皮質を短時 日の間に萎縮せしめる様な過大な副腎皮質反応を誘発しなかつた。乙れらの成績から推して著者の症例では 緩徐に冬眠状態を解除し得た事とクロールプロマジン ${ }^{37}$ を含む遮断カクテルを使用した事が術後の ACTH 分泌を抑制し得た主たる原因であろうと考えている。

\section{D. 副腎皮質反応指数について}

異なつた副腎皮質機能を有する個体を対象として手術反応量の絶対值をもつて相互に手術侵襲の大小を比 較する事は出来ない，臨床的にもとの傾向のある事は Marks ${ }^{29)}$ ， $\operatorname{Swan}^{45)}$ ，堂野前 ${ }^{6}$ 等の指摘している所であ る。著者はこのような観点から手術に対する副腎皮質反応とその個体自身の副腎皮質機能とを関係つけた指 数を用いれば手術そのものが脳下垂体副腎皮質系に及ぼす影響や，手術に付加される諸条件による変化を副 腎皮質反応性の等しい個体の間はもとより反応性の相異する個体相互間でも比較的明確に比較出来ると考え た. 肺上葉切除例について術前の負荷反応量と手術反応量の関係をみるとての範甩では正の相関が認められ たので (Fig. 13) 副粲皮質反応指数を考案した. 負荷反応量, 手術反応量は共に尿中 17-OHCS 排泄量の変 動量を取扱つているから，個体の ACTH 維持分泌量, 17-OHCS 基礎排泄量の相異にさして影響される事 なく脳下垂体副腎皮質系に及ぼす手術侵襲の大小を比較出来る。合併症の無い場合，常温下普通麻酔下に行

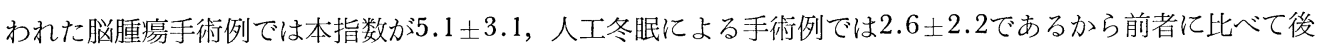
者は手術侵襲の影響が小であつたと考えられる。

\section{$\mathrm{V}$ 結論}

著者は脳腫瘍手術の術前術後の管理を改善しその治療成績を向上せしめる目的で各種脳腫瘍患者69例につ いて脳下垂体副腎皮質機能の面から術前の病態及び手術侵襲の影響を検討した.

1. 術前副腎皮質機能検查に ACTH-Z テストを用いるにあたり「負荷反応量」を導入した. その正常 範囲は8.0〜 42.0mgであつた．乙れを基準にして，正常反応，高反応，低反応の 3 型に分類した.

2. 脳腫瘍症例69例中14例の低反応と11例の高反応を認めた。高反応は脳腫痬にかなり特異な病態と考え られる。

3. 手術に対する脳下垂体副腎皮質反応を検討するにあたり「手術反応量」及び「副腎皮質反応指数」を 考案し，乙れを用いて人工冬眠下手術例の脳下垂体副腎皮質反応が常温下手術例に比べて小である事を示し 得た. 
稿总終るにあたり，㨸篤なる御指導，御鞭撻，御校閲を賜わつた。恩師武田義章教授に茲に深甚なる感謝 の意を表します。.

御指導を睗わつた。奈良医大堀浩教授，内海庄三郎助教授，阪大武田外科植田隆講師，実川佐太郎講師， 松岡健三博士，山村内科，熊谷朗講師に謝意学表します。

御教示, 御協力在賜わつた武田外科北川晃博士，中央臨床検查科武内和之博士に厚く感謝致します。御協 力を賜わつた阪大病院中央臨床検查科松下慶子博士，渡辺富久子氏，田中富美子氏，上田昭栄氏に謝意名表 します。

\section{参 考 文 献}

1) BAUER, H.G. : J. Clin. Endocrinol. \& Metab, $14: 13$, (1954).

2) BRILMAYER, H. :

Acta Endocrinologica, $31: 130$, (1959).

3) BRILMAYER, H. et al. : Dtsch. Zschr. Nervenheilk., $176: 427$, (1957). $\quad$ 4) BRILMAYER, H. et al. : Dtsch. Zschr. Nervenheilk., $176: 441$, (1957) 5) CHRISTY, N.P. et al. : J. Clin. Invest., 34 : 899, (1955).

6) 堂野前維摩 郷：心藏外科研究，(1958)，319，医学書院，東京.

7) EDGAHL, R.H. et al. : Endocrinology, $68: 574$, (1961). 8) EDGAHI, R.H. et al. : Surg. Gynec. \& Obst., 101:715, (1955). FISHER, R.G. et al. : Surgical Forum, $9: 683$, (1958). 10) FERRIMAN, D.G. et al. : Lancet, $1: 545$, (1954). 11) GELLER, J. et al. : J. Clin. Endocrinol. \& Metab., $17: 390$, (1957).

12) GURDJIAN, E.S. et al. : J.A.M.A., $158: 23$, (1955).

13) GRANT, F.C. : J. Neurosurg., $13: 479$, (1956). 14) GREEN, R. et al. : Lancet, $1: 543$, (1954). 15) HALME, A. et al. : Acta Endocrinologica, Supplement. $32: 3,(1957) . \quad 16)$ HAMMOND, W.G. et al. : Ann. Surg., $144: 715$, (1957).

17) HAMMOND, W.G. et al. : Ann. Surg., $148: 199$, (1958). 18) HELMREICH, M.L. et al. : Surgery, $41: 895$, (1957).

19) HÖGKFELT, B. et al. : Acta Endocrinologica, $32: 177$, (1959). 20) HOMAN, J.D.H. et al. : Lancet, $1: 541,(1954)$. 21) INGRAHM, F.D. et al. : New England J. Med., 246 : 568, (1952). 22) 石井昌三 : 日本外 科学会雑誌, $63: 13$, (1962). 23) 実川佐太郎, 他 : 外科研究の進歩, $8: 109$, (1958). 24) 桂重次, 他：脳と神経, $10: 311 ，(1958) . \quad 25)$ KUHL, W.J. et al. : New England J. Med., $263: 128,(1960)$. 26) 熊谷朗, 他 : 診療, $14: 33,(1961)$ 27) LAIDLAW, J.C. et al. : New England J. Med., $253: 745$, (1955). $\quad 28)$ LABORITT, H. et al. : (内苜耕二訳), 人 工冬眠療法の実際，(1955)，151，金芳堂，東京。 29 ) MARKS， L.J. et al. : Surgery，49:657, (1961). 30) MASON, J.W. et al. : Acta Neurovegetativa, $23: 4,(1961)$. 31) 三宅儀, 他 : 最新医学, $16: 1156$, (1961). 32) MOORE, F.D. et al. : Ann. Surg. $141: 145$, (1955).

33）宮崎正夫, 他：日本麻醉学会発表, (1961). 34$)$ NORTHFIELD, D.W.C. : Proc. Roy. Soc. Med., $48: 879$, (1955). 35$)$ NORTHFIELD, D.W.G. : Brain, $80: 293$, (1957). 36) 中 田瑞穂, 他 : 外科研究の進歩, $10: 3$, (1959). 37$)$ OLLING, G.C. et al. : Acta Endocrinologica, 23 : 283, (1956). 38) OUDSTEN, S.A. et al. : Lancet, $1: 541$, (1954). 39) PORTER, C.C. et al. : J.B.C. $185: 201,(1950)$ 40) REEGE, M.W. et al. : Surgery, $42: 669$, (1957). 41) REDDY, W.J. et al. : Metabolism, $1: 511$, (1952). $\quad 42)$ SEDZIMER, C.B. et al. : J. Neurosurg., $18: 199$, (1961). 43) STEENBURG, R.W.et al. : Ann. Surg., $143: 180$, (1956). 44) STEENBURG, R.W. : J. Glin. Endocrinol. \& Metab., $21: 39$, (1961). $\quad 45)$ SWAN, H. et al. : Surgery, $42:$ 202, (1957). 46) SETEKLEIV, J. et al. : J. Endocrinol., 22 : 119, (1961). 47) SGHWARTZ, T.B. : J. Clin. Endocrinol. \& Metab., $19: 269$, (1956). $\quad$ 48) TYTUS, J.S. et al. : J. Neurosurg., $12: 555$, (1955). 49) 武内和之：(未発表).

50) 魚住徹, 他：脳腫 
瘍患者の副腎皮質機能，第34回日本内分泌学会総会発表，(1961).

51）魚住徹, 他：脳手術患者の

管理及び麻酔について，其の一，日本麻醉学会第一回関西地方会発表，(1960).

52) VANDAM,

L.D. et al. : Anesthesiology, $21: 531$, (1960).

53) VIRTUE, R. : SURGERY, 41 : 549, (1957).

54) 渡辺冨久子 : 奈良医学雑誌, $11: 911,(1960)$. 